\title{
Factors Affecting Project Performance of IS Development: Evidence from Japanese IT Vendors
}

\author{
Tomoyuki KaWamura ${ }^{1, a)} \quad$ Kenichi Takano $^{1}$ \\ Received: April 15, 2013, Accepted: July 11, 2014
}

\begin{abstract}
Researchers have found that about $70 \%$ of information systems (IS) development projects in Japan have failed, thus increasing the demand for solutions that will increase expected project success rates. In this study, we seek to explore such a solution by identifying factors that affect the degree to which Japanese IS development projects succeed or fail. We accomplish this by using an Internet-based questionnaire and statistical analysis. The questionnaire, which was primarily comprised of questions related to CMMI, yielded responses from 650 project managers who work for Japanese IT vendors. Multivariate analyses and structure equation modeling techniques demonstrated that seven factors, "Ordering Company's Skill and Requirement," "Project Planning," "Detailed Planning and Product Quality in Each Phase," "Project Monitoring and Control," "Change Requirement Management," "Skill and Teamwork of Project Members," and "Schedule Progress in Each Phase" influence project performance. Results also showed that these factors covary.
\end{abstract}

Keywords: Information systems, project performance, CMMI, structural equation modeling

\section{Introduction}

The information technology (IT) industry has grown rapidly since the emergence of the commercial computer in the 1950s. One of the chief sub-industries of the information technology industry is referred to as information systems development. According to the Japan Users Association of Information Systems [1], IT vendors perform about $77 \%$ of all the work within the Japanese information systems development field. Further, the United States Department of Commerce [2] has claimed that IT vendors perform about $36 \%$ of all software development in the U.S. In addition to the large portion of IT-related work performed by Japanese IT vendors, investment in information systems development in Japan is increasing. For example, in 2011, over 100 billion U.S. dollars (USD) were invested in the Japanese information systems development industry [3]. That figure is expected to grow in the coming years.

Despite clear advances, projects within the Japanese information systems development industry are characterized by a relatively large rate of failure. This has become a concern for researchers and practitioners alike. McLeod and MacDonell [4], who surveyed previous research that has investigated factors of project failure, claim that conceptualizing project performance is difficult because it has been approached from various perspectives. Several definitions characterize project performance as the differences between expected and actual measures of quality, cost, and scheduling. Using this definition, Nikkei Business Publications (Nikkei BP) [5] and the Japan Users Association of Information Systems [1] have explored project performance in

\footnotetext{
Graduate School of System Design and Management, Keio University, Yokohama, Kanagawa 223-8526, Japan

a) tomoyuki@z5.keio.jp
}

Japan. According to Nikkei BP, about $70 \%$ of Japanese information systems development projects since 2003 have failed, despite expectations of increasing success rates. Similarly, the Standish Group [6] found that roughly $70 \%$ of software development projects in the U.S. have failed or been cancelled. In light of these issues, this research aims to reduce project failure rates by identifying factors that influence project performance. Specifically, we will focus on IT vendors as critical components of information systems development processes in Japan.

\section{Related Works}

To effectively explore those characteristics that affect project success, we focus on two key points: the IT vendor and the relationships between explanatory factors. We describe these key points below.

\subsection{IT Vendors}

As evidenced by the degree to which researchers have studied them, IT vendors play a critical role in information systems development in Japan. In a review of extant research on IT development, McLeod and MacDonell [4] identify a factor classification called "People and Action" that is related to project performance. Within this factor classification, the authors identify a sub-factor, which they referred to as a "developer". A significant amount of other research has also argued that due to their technical skill, experience, and communicative skills, developers heavily influence project performance. For example, Fitzgerald [7] and Fitzgerald et al. [8] argue that developers who possess a number of critical competencies increase productivity, and thus, project performance.

The literature has identified two types of development in which a developer can participate. The first, which is directly man- 


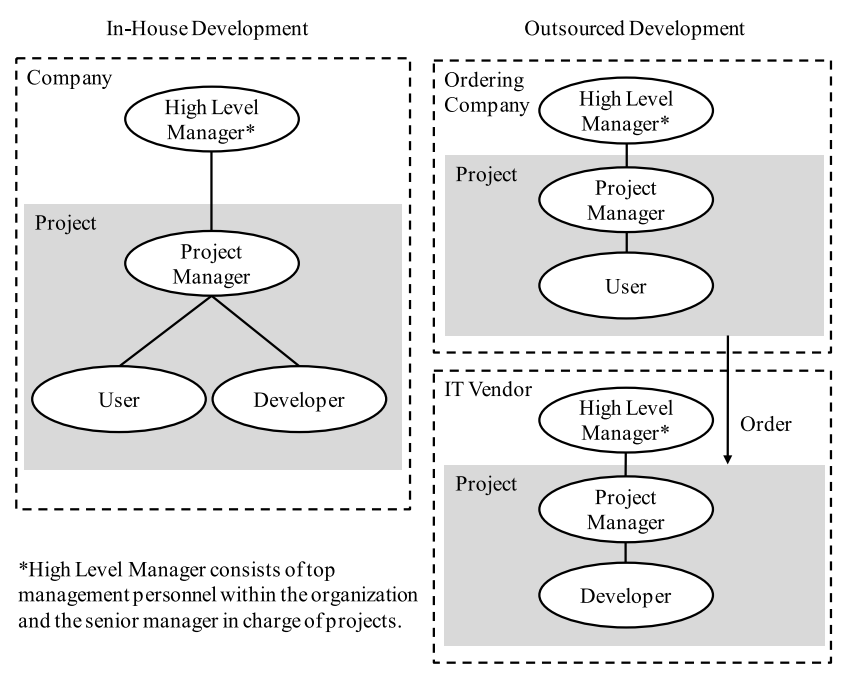

Fig. 1 Stakeholders of in-house development and outsourced development.

aged by the company that invests in the IT-development project, is called in-house development. With in-house development, all stakeholders including users and developers belong to the company that invests in information systems development. The second form of development, in which IT vendors receive external orders for information systems development, is called outsourced development. In this case, the user belongs to a company that invests in information systems development, and the developer belongs to an IT vendor. In this case, the IT vendor is more closely related to the above-mentioned "developer." See Fig. 1 for a graphical explanation of the two types of project development.

Despite the importance of the vendor in IT-project performance, there has been little research conducted on the topic. However, research that has been performed has been very useful. For example, on the basis of research of two software vendors, Iivari [9] argues that developers tend to develop systems for highly skilled users because they consider themselves typical users. Moreover, Furuyama and his colleagues [10] utilized a large number projects from large Japanese IT vendors as data to show the degree to which expected and actual performance differs. In addition, by investigating several IT vendors in China, Jun et al. [11] identifies factors that influence process performance and product performance. Although this research emphasized the influence of IT vendors on project performance, they neglected to explore the associations between its other predictors.

\subsection{Relationships between Explanatory Factors}

The second critical component related to the investigation of project performance relates to the associations between explanatory factors. In contrast to the research on the role of IT vendors, there is an abundance of research related to factors that influence project performance. However, most of this research has neglected to show that explanatory factors are mutually interrelated in some way. For example, The Standish Group [12] identified that "Lack of User Involvement" and "Incomplete Requirements" are predictors of project failure, but did not demonstrate that the former influences the latter. If the factors that are more proximal to the root can be specified, effective solutions for avoiding project failure can be implemented. Some studies have focused on relationships among these factors. For example, Gowan Jr. and Mathieu [13] used structural equation modeling (SEM) techniques to discover that technical complexity and project size influence project management, and that they affect project performance. Kawamura and Takano [14] also used SEM to test whether aspects of the organizational culture of an IT vendor affect project planning, which in turn affects project performance. Finally, Wixom and Watson [15] modeled the relationships between factors that affect data warehouse systems development. By employing partial least squares analysis, they likewise show that many of the explanatory factors are mutually influential. This extensive body of research has done much to clarify the relationships between factors that affect project performance. However, past research has neglected to incorporate the role of IT vendors in their analyses. Furthermore, the number of factors they explored was limited.

In response to these oversights, this study aims to identify factors that affect information systems development project performance by incorporating the two key points outlined above-the role of the IT vendor and the relationships among multiple factors. The methods through which this analysis was implemented are explained in the following section. The questionnaire we administered to collect data is outlined in Section 4. In Section 5 , the results will be presented, and Section 6 will offer some discussion related to these results. In Section 7, we offer some concluding remarks.

\section{Research Methods}

Although there are a number of available data collection methods that could be leveraged for the current investigation, we elected to use an Internet-based questionnaire. Relative to questionnaires distributed via conventional mail, which uses the entire resident register as the parent population, Internet-based questionnaires cannot account for people who are not familiar with the Internet (e.g., the elderly). However, because our analyses relate to factors that affect project performance, our research population consisted of developers, project managers (PM), and senior managers (SM) who work for an IT vendor (see Fig. 1), so issues related to unfamiliarity with the Internet were minimal. Further, some researchers state that if the Internet is available as a means to collect data, then it should be exploited [16], [17]. For these reasons, we elected to use an Internet-based questionnaire.

To procure a large sample from which to collect data, The NetMile Research service, which has access to the largest number of potential respondents in Japan (roughly 4.4 million as of April, 2012), was used to distribute the Internet questionnaire.

The questionnaire was comprised of a large number of questions. To avoid the necessity of analyzing an overwhelming amount of data related to each question, we extracted common factors among the items. Then, to identify factors that affect project performance and explore the associations between them, we leveraged structural equation modeling techniques on the questionnaire data.

In summary, our investigation was conducted with the following steps: 
- Create the questionnaire,

- Implement the questionnaire over the Internet,

- Compose dependent measure: "project performance,"

- Develop independent measures by extracting common factors from questions related to project activities, and

- Apply SEM to identify factors that significantly affect project performance and determine the nature of the relationships between the factors.

\section{Questionnaire}

\subsection{Questionnaire Design}

The questionnaire consists of four parts: attributes, project activities, project performance, and free answers. In constructing the questions, we used researches and a survey that were developed by the Information-Technology Promotion Agency of Japan [18], [19], [20], [21] as a guide. Brief synopses of each part of the questionnaire are offered in Sections 4.1.1-4.1.4, and each question described in Section 4.1.2 can be found in Table 4.

\subsubsection{Questionnaire Section: Attributes}

To specify influential characteristics of the respondent and project on which he/she works, a question class related to attributes was created. These questions related to the age of the respondent, the size of the company for which he/she works, the type of project on which he/she works, and other dispositional traits of the respondent and project. Thirteen questions were included in this section of the questionnaire.

\subsubsection{Questionnaire Section: Project Activities}

To identify the activities that the respondents felt critical for project performance, one portion of the questionnaire was directly related to project activities. We expected responses to this portion of the questionnaire to vary depending on which type of development life cycle the respondents' projects had adopted. Between $85-95 \%$ of Japanese IT projects adhere to the "waterfall" development life cycle [1], [21]. The waterfall model is a sequential development process, in which progress is seen as flowing steadily downwards through the phases of Requirement, Design, Implementation, Test, and Acceptance. West and Grant [22] argue that about $16 \%$ of IT projects use the waterfall model worldwide. Given (a) the large proportion of Japanese IT projects that adhere to the waterfall development life cycle, and (b) its applicability on projects that use the waterfall life cycle model, we referred to the Capability Maturity Model Integration [23] model to develop questions in this section. CMMI is a model that consists of 22 process areas. Nine of these process areas were of particular significance for our research, and were therefore used as guides in developing this section. These areas include: "Project Planning," "Project Monitoring and Control," "Risk Management," "Requirements Management," "Requirements Development," "Technical Solution," "Product Integration," "Verification," and "Validation."

The portion of the questionnaire related to project activities was also guided by McLeod and MacDonell's [4] "Development Processes" and "People and Action" classifications. Their "People and Action" classification relates to the skills and communication of each stakeholder. Therefore, we included the practices of not only IT vendor project members, but also stakeholders, SMs of the IT vendor, and ordering company project members, who correspond directly with IT vendor project members (see Fig. 1). See Table 1 for a summary of the elements that comprise the "Project Activities" section of the questionnaire.

\subsubsection{Questionnaire Section: Project Performance}

To determine the respective influences of various factors on project performance, it was necessary to construct an outcome measure that adequately gauged that performance. As such, one section of the questionnaire, entitled "Project Performance" was constructed.

Conceptualizing project performance is complicated because it has been approached from various perspectives [4]. Therefore, it is necessary to determine the definition of project performance appropriate for research purposes. Among the several viewpoints

Table 1 Main elements of project activities.

\begin{tabular}{|c|c|c|c|}
\hline \multirow{2}{*}{ Classification } & \multirow{2}{*}{$\begin{array}{l}\text { Corresponding process } \\
\text { areas of CMMI }\end{array}$} & \multicolumn{2}{|c|}{ Main elements of the questionnaire } \\
\hline & & Development Processes & People and Action \\
\hline Project Planning & - Project Planning & $\begin{array}{l}\text { - Conducting project planning activities } \\
\text { - Agreement of project planning with } \\
\text { stakeholders }\end{array}$ & $\begin{array}{l}\text { - PM skill } \\
\text { - Communication between PM, and ordering company and SM }\end{array}$ \\
\hline $\begin{array}{l}\text { Project Monitoring } \\
\text { and Control }\end{array}$ & $\begin{array}{l}\text { - Project Monitoring } \\
\text { and Control } \\
\text { - Risk Management }\end{array}$ & $\begin{array}{l}\text { - Monitoring and controlling project } \\
\text { - Management of risk } \\
\text { - Report to stakeholders }\end{array}$ & $\begin{array}{l}\text { - PM skill and resource } \\
\text { - Communication between PM, and ordering company, SM, and } \\
\text { project members }\end{array}$ \\
\hline $\begin{array}{l}\text { Change } \\
\text { Requirement } \\
\text { Management }\end{array}$ & $\begin{array}{l}\text { - Requirements } \\
\text { Management }\end{array}$ & - Management of change requirement & \\
\hline $\begin{array}{l}\text { Requirement } \\
\text { Development }\end{array}$ & $\begin{array}{l}\text { - Requirements } \\
\text { Development }\end{array}$ & $\begin{array}{l}\text { - Conducting requirement development } \\
\text { activities } \\
\text { - Management of requirement development } \\
\text { activities } \\
\text { - Agreement of requirement with stakeholders }\end{array}$ & $\begin{array}{l}\text { - Skill and resource of ordering company } \\
\text { - Skill and resource of project members } \\
\text { - Communication between ordering company and project } \\
\text { members } \\
\text { - Teamwork between project members }\end{array}$ \\
\hline Design & - Technical Solution & $\begin{array}{l}\text { - Conducting design activities } \\
\text { - Management of design activities } \\
\text { - Agreement of design with stakeholders }\end{array}$ & $\begin{array}{l}\text { - Skill and resource of project members } \\
\text { - Teamwork between project members }\end{array}$ \\
\hline Implementation & - Technical Solution & $\begin{array}{l}\text { - Conducting implementation activities } \\
\text { - Management of implementation activities }\end{array}$ & \\
\hline Test & $\begin{array}{l}\text { - Product Integration } \\
\text { - Verification }\end{array}$ & $\begin{array}{l}\text { - Conducting test activities } \\
\text { - Management of test activities }\end{array}$ & \\
\hline Acceptance Test & - Validation & $\begin{array}{l}\text { - Conducting acceptance test activities } \\
\text { - Management of acceptance test activities }\end{array}$ & $\begin{array}{l}\text { - Skill and resource of acceptance test members(ordering } \\
\text { company and/or IT vendor) } \\
\text { - Teamwork between acceptance test members }\end{array}$ \\
\hline
\end{tabular}


of project performance, Development Process/Product and Stakeholder, are considered in this research.

First, performance in terms of the Development Process/Product is discussed. Development Process evaluates whether the development project meets with the plan such as delivery date and budget [6], [15]. On the other hand, Product is an evaluation of the effectiveness of the product produced in terms of the quality and organization profit from the product [24]. Because this study aims to clarify factors that affect development project performance, we focus on the viewpoint of the Development Process. Hence, the difference between the planned and observed costs, schedules, quality, and scope is selected as the definition of project performance in this research.

Second, performance in terms of the Stakeholder is discussed. In the viewpoint of the Stakeholder, the condition whether the Development Process/Product satisfies the expectations of stakeholders is evaluated. Several researchers have surveyed whether they satisfy each stakeholder's expectation with respective criteria. For example, Riley and Smith [25] carried out different assessments of each stakeholder such as project team members, members outside the project team, and user, and evaluated project performance. From Fig. 1, four Stakeholders, high level manager of the ordering company, project of the ordering company, high level manager of the IT vendor, and project of the IT vendor, can be considered as objects for assessment in this research. Although the evaluation of satisfaction for all these stakeholders' expectation is important, satisfaction for expectation of the IT vendor project is surveyed in this research.

Thus, for this index, the difference between the planned and observed costs, schedules, quality, and scope from the viewpoint of the IT vendor project was determined as the definition of project performance with the following items:

- You developed the planned scope (function).

- You completed within the planned cost.

- You delivered within the planned schedule.

- The developed system was the quality after the delivery (the number of defects) that you expected.

Respondents were asked to evaluate these statements based on their estimations at the beginning of the project relative to their performances at the end of the project. Moreover, respondents evaluated their performances considering the change of plans. For example, in the case of an increase in observed cost by external factors of the IT vendor project such as change in requirement from the ordering company, the difference between the planned and observed cost will not be generated because the ordering company invests additional fee in the IT vendor project for the change. On the other hand, in the case of an increase in observed cost owing to internal factors of the IT vendor project such as poor cost estimation by the IT vendor, the difference between the planned and observed cost will be generated because nobody invests additional fee in the IT vendor project.

\subsubsection{Questionnaire Section: Free Answers}

Although the sections described above provided useful quantitative information related to factors that influence IT project performance, qualitative data can be similarly useful. Therefore, to collect additional information, two questions were posed that al- lowed the respondent to answer freely:

- What do you think is the most critical factor that affects project performance?

- What do you think is the best solution to improve the above factor?

Given our hope to generate valid quantitative data on the basis of this questionnaire, we produced alternatives forms of the questions in the Project Activities and Project Performance sections. Specifically, we created several items with corresponding six-point, Likert-type measures ranging from strongly positive to strongly negative.

Moreover, project cancellation is treated carefully. Cancellation implies that the project is interrupted without delivering any products that can be used [6], [26]. It is not always a bad thing. For example, in the case of cancellation owing to external factors of the IT vendor project such as the product becoming redundant for the ordering company before its completion, cancellation is not always a failure for the ordering company and the IT vendor because of controlling expenses and obtaining learning applicable to future projects. On the other hand, in the case of cancellation owing to internal factors of the IT vendor project such as the IT vendor not being able to develop any products for a technical reason, it can be considered as a significant failure for ordering company and the IT vendor. In this research, these cases are treated as project cancellations without any classification.

In the questionnaire, we structured the data such that results for questions that would be applicable after the project's cancellation were automatically changed. In this way, each respondent only provided data for those stages of the project that were completed prior to the project's cancellation.

\subsection{Validation of Questionnaire}

To ensure that the data produced by the questionnaire would be robust, factors related to project failure were compared with those identified by McLeod and MacDonell [4]. Additionally, three IT vendor specialists with expertise in the CMMI reviewed the questionnaire. Finally, to confirm that participants would be able to respond correctly, 10 PMs who work for IT vendors (with varying degrees of experience) answered and responded to the questionnaire.

\section{Results}

\subsection{Data Collection}

The questionnaire was distributed by the NetMile Research service. To be eligible to respond, participants were required to meet four conditions. First, they must work for an IT vendor. Second, they must have been a PM of an information systems development project which was completed no sooner than April 2007. Third, they must understand all aspects of the project they managed. Fourth, the project they managed was required to have adopted the waterfall life cycle development model. Given these conditions, 650 respondents completed the questionnaire on May 28, 2012.

Despite modest deviation, data normality for responses to the Project Activities and Project Performance sections of the questionnaire was confirmed with a visual inspection of their respec- 
tive distribution histograms.

\subsection{Selection of Valid Data}

To ensure that only valid data was incorporated into our analyses, we restricted our analyzable data on the basis of three conditions. First, we removed data that were derived from responses that took less than the seconds obtained after multiplying the number of questions by two. Based on this stipulation, 79 data points were disqualified from analysis. Second, data that were logically inconsistent (i.e., when current age minus years of experience in the IT industry was less than 15 , when current age minus years of experience as a PM was less than 18) were considered invalid. This led to the removal of eight data points. Finally, data that indicated a clear misunderstanding of the questionnaire (as demonstrated through the free answers) were considered invalid, thus resulting in the removal of nine respondents from the dataset. Based on these criteria, 88 respondents were removed from the dataset. This resulted in a final sample of 562 respondents.

\subsection{Distribution of Respondents}

Within our dataset, the average respondent was 42.1 years old and possessed 18.1 years of experience in the IT industry, 8.7 of which were as a PM experience. In this area of study, these figures are relatively similar to those found in other investigations [27], [28]. Distributions of attributes are summarized in Table 2 .

\subsection{Data Analysis}

The scope of these data was largely dependent on individual project cancellation. As shown in Table 2, 520 projects $(92.5 \%)$ were not cancelled at any stage. This is in sharp contrast to the findings of the Standish Group [6] and Emam and Koru [26], who respectively reported that $24 \%$ and $11.5 \%$ of projects are cancelled. The comparatively low cancellation rate evident in our data may be due to the possibility that project cancellation in Japan is low relative to the rest of the world.

Missing data would normally represent a barrier to multivariate analysis, but we collected sufficient data to remove those cases in which cancellation had taken place. Therefore, we further reduced our sample to 520. To perform the statistical analyses, we used the SPSS Statistics Package v.20. We used SPSS AMOS Additional Package v.20 to leverage structure equation modeling on our data.

\subsubsection{Composition and Factor Analysis of Questions}

To prepare the raw data for analysis, it was necessary to reduce the individual questions into interpretable factors and indices. First, Project Performance, which consists of four questions, was transformed into one index variable to serve as an outcome measure to balance project quality, cost, schedule, and scope [29]. To construct this measure, responses to the questions in the Project Performance section of the questionnaire were averaged, yielding the response variable, Project Performance (Y). The reliability estimate of Y was sufficiently high $($ Cronbach's alpha $=0.839)$ to confirm consistency across the index.

Second, predictors of project performance were extracted by
Table 2 Data distribution.

\begin{tabular}{|c|c|c|c|}
\hline Attributes & Alternatives & $\mathrm{N}$ & $\%$ \\
\hline \multirow[t]{2}{*}{ Sex } & Male & 533 & 94.8 \\
\hline & Female & 29 & 5.2 \\
\hline \multirow{5}{*}{$\begin{array}{l}\text { Company } \\
\text { size }\end{array}$} & 100 employees or less & 187 & 33.3 \\
\hline & Between 101 and 300 employees & 67 & 11.9 \\
\hline & Between 301 and 1000 employees & 101 & 18.0 \\
\hline & Between 1001 and 3000 employees & 98 & 17.4 \\
\hline & 3001 employees or more & 109 & 19.4 \\
\hline \multirow{6}{*}{$\begin{array}{l}\text { Project } \\
\text { completion } \\
\text { year }\end{array}$} & Fiscal year 2007 & 37 & 6.6 \\
\hline & Fiscal year 2008 & 44 & 7.8 \\
\hline & Fiscal year 2009 & 52 & 9.3 \\
\hline & Fiscal year 2010 & 93 & 16.5 \\
\hline & Fiscal year 2011 & 187 & 33.3 \\
\hline & Fiscal year 2012 & 149 & 26.5 \\
\hline \multirow{5}{*}{$\begin{array}{l}\text { Project } \\
\text { period }\end{array}$} & Fewer than 3 months & 59 & 10.5 \\
\hline & Between 3 and 6 months & 153 & 27.2 \\
\hline & Between 6 and 12 months & 184 & 32.7 \\
\hline & Between 12 and 18 months & 92 & 16.4 \\
\hline & 18 months or more & 74 & 13.2 \\
\hline \multirow{4}{*}{$\begin{array}{l}\text { Man-months } \\
\text { of project }\end{array}$} & Less than 30 man-months & 198 & 35.2 \\
\hline & Between 30 and 100 man-months & 213 & 37.9 \\
\hline & Between 101 and 500 man-months & 107 & 19.0 \\
\hline & 501 man-months or more & 44 & 7.8 \\
\hline \multirow[t]{4}{*}{ Project type } & New development & 234 & 41.6 \\
\hline & $\begin{array}{l}\text { Small enhancement to the existing system (less } \\
\text { than } 10 \% \text { enhancement of the system) }\end{array}$ & 75 & 13.3 \\
\hline & $\begin{array}{l}\text { Enhancement of the existing system (more than } \\
10 \% \text { enhancement of the system) }\end{array}$ & 159 & 28.3 \\
\hline & $\begin{array}{l}\text { Re-development of the existing system } \\
\text { (changes in system hardware and/or } \\
\text { middleware without changing software } \\
\text { specification) }\end{array}$ & 94 & 16.7 \\
\hline \multirow{6}{*}{$\begin{array}{l}\text { Project } \\
\text { cancellation }\end{array}$} & No cancellation & 520 & 92.5 \\
\hline & Conduct requirement development, then cancel & 15 & 2.7 \\
\hline & $\begin{array}{l}\text { Conduct requirement development and design, } \\
\text { then cancel }\end{array}$ & 13 & 2.3 \\
\hline & $\begin{array}{l}\text { Conduct requirement development, design, and } \\
\text { implementation, then cancel }\end{array}$ & 6 & 1.1 \\
\hline & $\begin{array}{l}\text { Conduct requirement development, design, } \\
\text { implementation, and test, then cancel }\end{array}$ & 3 & 0.5 \\
\hline & $\begin{array}{l}\text { Conduct requirement development, design, } \\
\text { implementation, test, and acceptance test, then } \\
\text { cancel }\end{array}$ & 5 & 0.9 \\
\hline
\end{tabular}

Table 3 Correlation matrix of response variable and factors.

\begin{tabular}{|c|c|c|c|c|c|c|c|c|c|c|c|c|}
\hline & $\mathrm{X} 1 \mathrm{X} 2$ & $\mathrm{X} 3$ & $\mathrm{X} 4$ & $\mathrm{X} 5$ & X6 & $\mathrm{X} 7$ & $\mathrm{X} 8$ & $\mathrm{X} 9$ & $\mathrm{X} 10$ & X11 & $\mathrm{X} 12$ & $\mathrm{Y}$ \\
\hline $\mathrm{X} 1$ & $-.457^{* *}$ & $.720^{* *}$ & $.557^{* *}$ & $.512 * *$ & $.691^{* *}$ & $.304 * *$ & $.628^{* *}$ & $.536 * *$ & $.587 * *$ & $.591^{* *}$ & $.130^{* *}$ & *.739** \\
\hline $\mathrm{X} 2$ & - & $.508^{* *}$ & $.492^{* *}$ & $.474 * *$ & $.624^{* *}$ & $.472 * *$ & $.379^{* *}$ & $.445^{* *}$ & $.525^{* *}$ & $.551^{* *}$ & -.012 & $.466^{* *}$ \\
\hline $\mathrm{X} 3$ & & - & $.581^{* *}$ & $.597 * *$ & $.709^{* *}$ & $.294^{* *}$ & $.578^{* *}$ & $.626^{* *}$ & $.526^{* *}$ & $.652^{* *}$ & $.095^{*}$ & $.658^{* *}$ \\
\hline $\mathrm{X} 4$ & & & - & $.512 * *$ & $.630^{* *}$ & $.334 * *$ & $.449^{* *}$ & $.464 * *$ & $.441^{* *}$ & $.526^{* *}$ & .062 & $.538^{* *}$ \\
\hline $\mathrm{X} 5$ & & & & - & $.573^{* *}$ & $.317^{* *}$ & $.417^{* *}$ & $.450^{* *}$ & $.521^{* *}$ & $.513 * *$ & .044 & $.480^{* *}$ \\
\hline $\mathrm{X} 6$ & & & & & - & $.345^{* *}$ & $.633^{* *}$ & $.515^{* *}$ & $.572 * *$ & $.719^{* *}$ & -065 & $.688^{* *}$ \\
\hline $\mathrm{X} 7$ & & & & & & - & $.257^{* *}$ & $.266 * *$ & $.349^{* *}$ & $.403 * *$ & .067 & $.267 * *$ \\
\hline $\mathrm{X} 8$ & & & & & & & - & $.475 * *$ & $.527^{* *}$ & $.473 * *$ & $.166^{* *}$ & $* .752 * *$ \\
\hline $\mathrm{X} 9$ & & & & & & & & - & $.454^{* *}$ & $.485^{* *}$ & $.153^{* *}$ & $* .561^{* *}$ \\
\hline $\mathrm{X} 10$ & & & & & & & & & - & $.582 * *$ & $.119^{* *}$ & * . $.548^{* *}$ \\
\hline X11 & & & & & & & & & & - & -.054 & $.553^{* *}$ \\
\hline $\mathrm{X} 12$ & & & & & & & & & & & - & .083 \\
\hline $\mathrm{Y}$ & & & & & & & & & & & & - \\
\hline
\end{tabular}

applying maximum-likelihood factor analysis with Promax rotation to the 91 questions in the Project Activities section of the questionnaire. As a result of the analysis, 12 factors emerged as explanatory variables. The 12 factors explained $72.0 \%$ of the variance in the 91 questions of the Project Activities section prior to rotation. The correlations between the response variable and the factors are shown in Table 3, and the post-rotation pattern matrix is shown in Table 4. 
Following the factor analysis, we assigned each factor a name on the basis of the questions that comprise them. These names are listed in Table $\mathbf{5}$.

\subsubsection{Analysis of Relation of Factors}

To explore the relationships between the factors that affect project performance, we leveraged SEM and multiple regression analysis to define paths between them. The results of these analyses are detailed in this section.

First, we employed multiple regression analysis to explore the effect of explanatory factors on project performance. Because not all explanatory variables might influence project performance, we applied the stepwise method. The stepwise method automatically extracts explanatory variables, which show most dominant F-value by repeatedly carrying out addition/removal of explanatory variables and multiple regression analysis. As a result, four explanatory variables: Schedule Progress in Each Phase (X8), Skill and Teamwork of Project Members (X1), Detailed Planning and Product Quality in Each Phase (X6), and Test (X9) were extracted. Given the extraction of these factors, the adjusted $\mathrm{R}^{2}$ of the model was 0.706, indicating a good fit to the data (Table 6).

Second, a model was created by adding factors that have strong significant correlation coefficients from Table 3 to the multiple regression modeling. In order to obtain an optimal model, addition/removal of factors and paths between factors, and the analysis of SEM were repeatedly carried out until an effective SEM index was obtained. As a result, the model of Fig. 2 whose fit index of SEM was sufficient was obtained (see Table 7). In addition, because a model that included X3, X7, X9, X10, or X12 did not show sufficient fit index of SEM, it was concluded that the influences of these factors were relatively small, and these factors

Table 4 Factor analysis result of project activities.

\begin{tabular}{|c|c|c|c|c|c|c|c|c|c|c|c|c|c|}
\hline & & \multicolumn{12}{|c|}{ Factor } \\
\hline & & $\mathrm{X} 1$ & $\mathrm{X} 2$ & $\mathrm{X} 3$ & $\mathrm{X} 4$ & $\mathrm{X} 5$ & $\mathrm{X} 6$ & $\mathrm{X} 7$ & $\mathrm{X} 8$ & $\mathrm{X} 9$ & $\mathrm{X} 10$ & $\mathrm{X} 11$ & $\mathrm{X} 12$ \\
\hline \multicolumn{14}{|c|}{ X1: Skill and Teamwork of Project Members } \\
\hline Q15_6 & $\begin{array}{l}\text { (Implementation) The project members had enough technology skill used for } \\
\text { the development. }\end{array}$ & 1.040 & .081 & .013 & -.057 & -.022 & -.083 & -.037 & .000 & .013 & .083 & -.064 & .039 \\
\hline Q15_5 & $\begin{array}{l}\text { (Implementation) The project members' capability (understanding of the } \\
\text { design, implementation experience, etc.) was enough. }\end{array}$ & 1.015 & .036 & .010 & -.049 & .037 & -.079 & .032 & .061 & .096 & -.020 & -.154 & -.056 \\
\hline Q14_8 & $\begin{array}{l}\text { (Design) The project members had enough technology skill used for the } \\
\text { development. }\end{array}$ & .971 & .058 & -.163 & -.003 & .081 & -.045 & .032 & -.040 & -.041 & .005 & -.045 & .097 \\
\hline Q14_7 & $\begin{array}{l}\text { (Design) The project members' capability (understanding of the requirement, } \\
\text { design experience, etc.) was enough. }\end{array}$ & .846 & .036 & -.048 & .151 & .008 & -.049 & .055 & -.068 & .003 & -.144 & .030 & .025 \\
\hline Q15_4 & $\begin{array}{l}\text { (Implementation) By the influence of the technology used for the } \\
\text { development (programming language, middleware, a package, etc.), problem } \\
\text { did not occur in the implementation. }\end{array}$ & .646 & -.123 & .203 & -.107 & -.011 & .170 & -.043 & .060 & -.060 & .032 & .014 & -.027 \\
\hline Q16_6 & (Test) The project members had enough technology skill used for the test. & .632 & .000 & .040 & -.041 & -.009 & .036 & -.056 & -.165 & .254 & .079 & .011 & .267 \\
\hline Q15_9 & $\begin{array}{l}\text { (Implementation) Information for the implementation was shared between } \\
\text { project members. }\end{array}$ & .615 & -.098 & .029 & -.086 & .005 & .108 & -.001 & .046 & .009 & .189 & .042 & -.018 \\
\hline Q14_10 & (Design) The teamwork between project members was good. & .611 & .049 & -.005 & -.004 & -.004 & -.042 & -.048 & .074 & -.091 & .112 & .008 & -.015 \\
\hline Q15_8 & (Implementation) The teamwork between project members was good. & .601 & -.093 & -.014 & -.128 & -.034 & .126 & -.002 & .119 & -.105 & .420 & -.031 & -.056 \\
\hline Q12_11 & $\begin{array}{l}\text { (Requirement Development) The project members' capability (operation } \\
\text { knowledge, experience, etc.) was enough. }\end{array}$ & .586 & -.064 & -.017 & .179 & -.031 & -.106 & .053 & .000 & .077 & .137 & .038 & .129 \\
\hline Q14_11 & (Design) Information for the design was shared between project members. & .584 & .095 & .017 & -.034 & .018 & .050 & -.018 & .002 & -.021 & -.006 & .005 & -.007 \\
\hline Q16_5 & $\begin{array}{l}\text { (Test) The project members' capability (understanding of the design and the } \\
\text { implementation, test experience, etc.) was enough. }\end{array}$ & .572 & .073 & .025 & .056 & -.004 & -.067 & -.036 & .003 & .415 & -.111 & -.022 & .140 \\
\hline Q15_7 & $\begin{array}{l}\text { (Implementation) The project members' resource (working hours, the number } \\
\text { of members, etc.) was enough. }\end{array}$ & .551 & -.031 & .007 & .082 & -.038 & .218 & .051 & .122 & -.033 & -.068 & .008 & .318 \\
\hline Q15_10 & $\begin{array}{l}\text { (Implementation) The environment for the implementation (programming } \\
\text { tool, etc.) was ready. }\end{array}$ & .528 & -.062 & .033 & -.092 & .002 & 157 & -.013 & .077 & .056 & .110 & .007 & .042 \\
\hline Q14_6 & $\begin{array}{l}\text { (Design) By the influence of the technology used for development, a problem } \\
\text { did not occur in design. }\end{array}$ & .508 & -.100 & -.016 & .129 & .011 & .217 & -.003 & .048 & -.045 & -.208 & .173 & .033 \\
\hline Q16_9 & (Test) Information for the test was shared between project members. & .483 & .059 & .142 & -.103 & .024 & -.116 & -.063 & .022 & .266 & .116 & .014 & .032 \\
\hline Q16_8 & (Test) The teamwork between project members was good. & .465 & .022 & .220 & -.103 & -.025 & -.170 & -.085 & .081 & .212 & .193 & -.033 & .021 \\
\hline Q14_9 & $\begin{array}{l}\text { (Design) The project members' resource (working hours, the number of } \\
\text { members, etc.) was enough. }\end{array}$ & .457 & -.020 & .025 & .162 & .038 & .138 & -.014 & .025 & -.228 & -.075 & .161 & .454 \\
\hline Q12_16 & $\begin{array}{l}\text { (Requirement Development) Information for the requirement development } \\
\text { was shared between project members. }\end{array}$ & .414 & .046 & .034 & .082 & -.039 & .064 & .042 & -.066 & -.071 & .345 & -.023 & .031 \\
\hline \multicolumn{14}{|c|}{ X2: Project Planning } \\
\hline Q9_2 & $\begin{array}{l}\text { (Project Planning) You examined the base of estimation (the contents of } \\
\text { work, required resource, technology, etc.), and planned cost. }\end{array}$ & .015 & .795 & .037 & -.014 & -.054 & -.011 & -.035 & .092 & -.033 & -.012 & .045 & -.041 \\
\hline Q9_3 & $\begin{array}{l}\text { (Project Planning) You examined the base of estimation (the contents of } \\
\text { work, required resource, technology, etc.), and planned schedule. }\end{array}$ & .027 & .762 & -.033 & -.093 & .009 & .270 & -.040 & .052 & -.106 & .060 & -.061 & .112 \\
\hline Q9_4 & $\begin{array}{l}\text { (Project Planning) You examined the base of estimation (the contents of } \\
\text { work, required resource, technology, etc.), and set up target quality. }\end{array}$ & -.042 & .761 & .193 & -.014 & -.017 & -.002 & -.006 & .039 & -.084 & -.128 & .127 & .061 \\
\hline Q9_1 & $\begin{array}{l}\text { (Project Planning) Considering the ordering company's demand, you } \\
\text { specified the project scope (functions, processing speed, etc.). }\end{array}$ & -.062 & .700 & .073 & -.005 & .049 & .046 & -.021 & .035 & -.062 & .072 & -.034 & -.061 \\
\hline Q9_6 & $\begin{array}{l}\text { (Project Planning) You collected information for the project planning from } \\
\text { the ordering company. }\end{array}$ & .068 & .657 & -.048 & .050 & .048 & -.011 & -.066 & -.166 & .042 & .136 & -.007 & -.108 \\
\hline Q9_7 & $\begin{array}{l}\text { (Project Planning) You contracted with the ordering company based on the } \\
\text { document that indicated sufficient contents. }\end{array}$ & -.005 & .604 & -.086 & .085 & .039 & -.121 & .002 & -.035 & .019 & .012 & .083 & -.073 \\
\hline Q9_5 & (Project Planning) You specified serious risk and issue. & -.139 & .543 & .066 & -.050 & -.016 & -.042 & .157 & .010 & .071 & -.121 & .219 & .010 \\
\hline Q9-8 & $\begin{array}{l}\text { (Project Planning) Your capability of the project planning (project } \\
\text { management skill, operation knowledge, etc.) was enough. }\end{array}$ & .339 & .390 & -.156 & -.083 & -.111 & .051 & .085 & .122 & -.071 & .092 & .206 & .008 \\
\hline Q9_11 & $\begin{array}{l}\text { (Project Planning) The project members understood the contents of the } \\
\text { project planning. }\end{array}$ & .346 & .376 & -.023 & -.004 & -.041 & -.062 & .193 & -.118 & .040 & .298 & -.035 & -.051 \\
\hline Q12_1 & $\begin{array}{l}\text { (Requirement Development) You considered the work procedure of } \\
\text { requirement development. }\end{array}$ & .043 & .275 & .131 & .092 & .051 & .269 & -.084 & -.129 & -.007 & .110 & .060 & .021 \\
\hline \multicolumn{14}{|c|}{ X3: Acceptance Test } \\
\hline Q17_3 & (Acceptance Test) You carried out the planned acceptance test. & -.124 & -.034 & .836 & -.031 & -.054 & .162 & .100 & .024 & .097 & .018 & -.032 & -.084 \\
\hline Q17_5 & $\begin{array}{l}\text { (Acceptance Test) The acceptance test members' capability (understanding } \\
\text { of the order company's requirement, test experience, etc.) was enough. }\end{array}$ & .108 & .013 & .813 & .084 & .015 & -.146 & -.008 & -.055 & .114 & -.025 & -.049 & .043 \\
\hline Q17_4 & $\begin{array}{l}\text { (Acceptance Test) The scope of the acceptance test was enough to ensure that } \\
\text { the system can be used actually. }\end{array}$ & .033 & .028 & .804 & .066 & -.006 & .000 & .043 & -.001 & .155 & -.085 & -.101 & -.043 \\
\hline Q17_7 & $\begin{array}{l}\text { (Acceptance Test) The teamwork between acceptance test members was } \\
\text { good. }\end{array}$ & .231 & -.078 & .802 & -.119 & .050 & -.231 & .031 & -.010 & -.083 & .256 & .041 & .034 \\
\hline Q17_1 & (Acceptance Test) You considered the work procedure of acceptance test. & -.084 & .049 & .791 & .033 & .030 & .159 & .039 & -.150 & -.074 & -.011 & .070 & -.015 \\
\hline Q17_8 & $\begin{array}{l}\text { (Acceptance Test) Information for the acceptance test was shared between } \\
\text { acceptance test members. }\end{array}$ & .157 & -.031 & .787 & -.023 & .029 & -.102 & -.021 & -.043 & -.124 & .161 & .084 & .133 \\
\hline Q17_2 & (Acceptance Test) You planned a feasible schedule. & -.128 & .074 & .762 & -.055 & -.015 & .280 & .041 & .073 & .035 & -.025 & -.086 & -.025 \\
\hline Q17_9 & $\begin{array}{l}\text { (Acceptance Test) The environment for the acceptance test (test tool, etc.) } \\
\text { was ready. }\end{array}$ & .075 & .032 & .731 & .077 & .000 & -.099 & -.095 & -.011 & -.031 & -.016 & .186 & .174 \\
\hline Q17_6 & $\begin{array}{l}\text { (Acceptance Test) The acceptance test members' resource (working hours, } \\
\text { the number of members, etc.) was enough. }\end{array}$ & .165 & .024 & .694 & .067 & .015 & -.038 & .019 & -.061 & .010 & -.147 & .025 & .314 \\
\hline Q17_10 & $\begin{array}{l}\text { (Acceptance Test) You completed the acceptance test within the planned } \\
\text { schedule. }\end{array}$ & .003 & .045 & .639 & .047 & .033 & -.098 & .001 & .426 & .094 & -.004 & -.114 & -.085 \\
\hline
\end{tabular}


X4: Ordering Company's Skill and Requirement

Q12_8 (Requirement Development) The capability of the ordering company

Q12_9 (Requirement Development) The ordering company's resource (working hours, the number, etc.) was enough.

Q12_10 (Requirement Development) Decision-making of the ordering company was

Q12_4 (Requirement Development) The requirement of the ordering company was

Q12_7 (Requirement Development) The check for the scope (review, etc.) which

Q126 (Requirement Development) The scope (functions, processing speed, etc.) which would be realized by the systems were clear

Q12_5 (Requirement Development) It was examined that the requirement of the ordering company would suit actual operation.

X5: Change Requirement Management
Q13_5 (Change Requirement Management) You agreed with the ordering company about the necessity for change.

Q13_4 (Change Requirement Management) You agreed with the project members about the necessity for change.

Q13_3 (Change Requirement Management) The change requirement was within a range that the project could deal with

Q13_2 (Change Requirement Management) You investigated the solution for the change requirement properly.

Q13_1 (Change Requirement Management) The start conditions of change requirement management were clear (for example, additional cost will be charged for change requirement, after the completion of requirement development.).

\begin{tabular}{|c|c|c|c|c|c|c|c|c|c|c|c|c|c|}
\hline \multicolumn{14}{|c|}{ X6: Detailed Planning and Product Quality in Each Phase } \\
\hline Q14_2 & $\begin{array}{l}\text { (Design) You planned a feasible schedule. } \\
\text {. }\end{array}$ & .070 & .094 & -.005 & -.146 & .068 & .889 & -.027 & -.074 & .089 & -.053 & -.087 & .166 \\
\hline Q15_2 & (Implementation) You planned a feasible schedule. & .118 & -.051 & .020 & -.147 & .019 & .832 & .005 & .087 & .013 & .031 & -.008 & .122 \\
\hline Q12_2 & (Requirement Development) You planned a feasible schedule. & -.065 & .157 & -.083 & -.087 & .019 & .794 & -.009 & -.050 & .096 & .152 & -.081 & .162 \\
\hline Q16 2 & (Test) You planned a feasible schedule. & -.036 & -.029 & .135 & -.134 & -.003 & .501 & .015 & .059 & .489 & .127 & -.056 & .135 \\
\hline Q14_1 & (Design) You considered the work procedure of design. & .018 & .137 & .134 & .053 & .034 & .455 & -.037 & -.115 & .119 & -.150 & .159 & .039 \\
\hline Q14_3 & (Design) You designed the contents of the requirement development. & .104 & .068 & .118 & .085 & -.020 & .443 & -.023 & -.014 & .100 & -.090 & .134 & -.107 \\
\hline Q15_3 & (Implementation) You implemented the contents of the design. & .294 & .014 & .101 & -.015 & -.059 & .378 & .022 & .135 & .106 & -.089 & .039 & -.132 \\
\hline Q12_3 & $\begin{array}{l}\text { (Requirement Development) You investigated the requirement of the } \\
\text { ordering company. }\end{array}$ & -.050 & .092 & .116 & .267 & -.054 & .337 & -.027 & -.065 & .098 & .191 & .057 & -.006 \\
\hline Q14_5 & $\begin{array}{l}\text { (Design) It was examined that the technology used for the development } \\
\text { (programming language, middleware, package, etc.) would suit the system. }\end{array}$ & .192 & -.040 & .132 & .042 & .098 & .315 & -.018 & -.111 & .030 & -.120 & .253 & -.101 \\
\hline Q15_1 & $\begin{array}{l}\text { (Implementation) You considered the work procedure of implementation } \\
\text { (programming rule, etc.). }\end{array}$ & .181 & .071 & .244 & -.030 & .015 & .315 & -.061 & -.131 & .007 & -.001 & .177 & -.028 \\
\hline Q14 4 & (Design) The check of the design (review, etc.) was enough. & .124 & -.057 & .123 & .117 & .022 & .283 & .036 & .017 & .133 & -.001 & .234 & .002 \\
\hline \multicolumn{14}{|c|}{ X7: SM Involvement } \\
\hline Q10_10 & $\begin{array}{l}\text { (Project Monitoring and Control) SM tackled to solve the important } \\
\text { problems (a member's addition etc.) which PM could not deal with. }\end{array}$ & .004 & -.143 & .008 & .044 & -.003 & -.075 & .872 & -.018 & .060 & .101 & .097 & .036 \\
\hline Q9_10 & $\begin{array}{l}\text { (Project Planning) SM tackled to solve the important problems (project } \\
\text { members' assignment, etc.) which PM could not deal with. }\end{array}$ & .008 & .145 & .023 & -.016 & .023 & -.025 & .809 & -.078 & -.001 & -.084 & -.045 & .063 \\
\hline Q10_9 & (Project Monitoring and Control) SM had grasped the situation of the project. & -.010 & -.101 & .022 & .006 & .054 & .003 & .777 & .041 & -.020 & .065 & .125 & .017 \\
\hline Q9 9 & (Project Planning) SM understood the contents of Project Planning. & .022 & .180 & .086 & -.056 & -.025 & .021 & .769 & .024 & .021 & -.034 & -.108 & -.053 \\
\hline \multicolumn{14}{|c|}{ X8: Schedule Progress in Each Phase } \\
\hline Q15_11 & $\begin{array}{l}\text { (Implementation) You completed the implementation within the planned } \\
\text { schedule. }\end{array}$ & .245 & .008 & -.041 & .064 & .026 & -.090 & -.013 & .793 & .021 & -.052 & .098 & -.070 \\
\hline Q16_11 & (Test) You completed the test within the planned schedule. & .147 & .027 & .057 & -.002 & .072 & -.150 & -.034 & .650 & .320 & -.050 & .000 & .045 \\
\hline Q14_12 & (Design) You completed the design within the planned schedule. & .181 & -.040 & -.051 & .004 & .052 & .286 & .024 & .531 & -.043 & .035 & -.087 & 144 \\
\hline Q12_17 & $\begin{array}{l}\text { (Requirement Development) You completed the requirement development } \\
\text { within the planned schedule. }\end{array}$ & .137 & .036 & -.093 & .116 & .010 & .139 & -.022 & .453 & -.039 & .156 & .071 & .064 \\
\hline \multicolumn{14}{|c|}{ 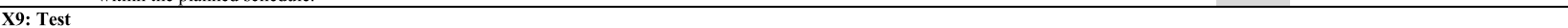 } \\
\hline Q16 3 & (Test) You carried out the planned test. & .159 & -.024 & .139 & -.035 & -.041 & .101 & .104 & .114 & .586 & -.057 & -.018 & -.129 \\
\hline Q16_4 & $\begin{array}{l}\text { (Test) The scope of the test was enough to ensure the quality of the system } \\
\text { (the function is fully developed, etc.). }\end{array}$ & .129 & .006 & .216 & .044 & -.028 & .083 & .004 & .123 & .504 & -.130 & .054 & -.007 \\
\hline Q16_1 & (Test) You considered the work procedure of the test. & -.041 & .007 & .272 & -.075 & .015 & .206 & -.015 & -.099 & .492 & .028 & .128 & .014 \\
\hline Q16_10 & (Test) The environment for the test (test tool, etc.) was ready. & .251 & .025 & .178 & -.005 & -.013 & -.098 & -.121 & .129 & .306 & .080 & .108 & .151 \\
\hline \multicolumn{14}{|c|}{ X10: Communication in Requirement Development, and Project Monitoring and Control } \\
\hline Q12_15 & $\begin{array}{l}\text { (Requirement Development) The teamwork between project members was } \\
\text { good. }\end{array}$ & .486 & -.028 & .001 & -.038 & .003 & .073 & .069 & -.016 & -.079 & .525 & -.149 & -.014 \\
\hline Q12_13 & $\begin{array}{l}\text { (Requirement Development) The communication between the ordering } \\
\text { company and project members was good. }\end{array}$ & .233 & .025 & -.026 & .291 & .066 & .019 & .026 & -.077 & .069 & .490 & -.223 & .107 \\
\hline Q12_14 & $\begin{array}{l}\text { (Requirement Development) Information for the requirement development } \\
\text { was shared between the ordering company and the project members. }\end{array}$ & .221 & .068 & -.025 & .298 & .036 & .034 & .012 & -.060 & -.026 & .482 & -.082 & .130 \\
\hline Q10_12 & $\begin{array}{l}\text { (Project Monitoring and Control) The communication between the ordering } \\
\text { company and you was good. }\end{array}$ & -.085 & .292 & -.093 & .155 & .048 & -.103 & -.047 & .149 & .078 & .445 & .182 & -.090 \\
\hline Q10_13 & $\begin{array}{l}\text { (Project Monitoring and Control) The communication between the project } \\
\text { members and you was good. }\end{array}$ & .166 & .291 & .037 & -.160 & -.015 & .029 & -.042 & -.037 & .001 & .432 & .211 & -.059 \\
\hline Q10_14 & $\begin{array}{l}\text { (Project Monitoring and Control) Information of the project was shared } \\
\text { between the project members and you. }\end{array}$ & .166 & .277 & .101 & -.095 & -.038 & -.042 & -.014 & -.021 & -.101 & .413 & .297 & -.023 \\
\hline \multicolumn{14}{|c|}{ X11: Project Monitoring and Control } \\
\hline Q10_3 & $\begin{array}{l}\text { (Project Monitoring and Control) You had been monitoring the actual values } \\
\text { of quality (the number of review defects, the number of test defects, etc.). }\end{array}$ & -.044 & .337 & .170 & .045 & .044 & -.158 & -.002 & .033 & -.011 & -.047 & .601 & .014 \\
\hline Q10_5 & $\begin{array}{l}\text { (Project Monitoring and Control) You had specified serious risk and issue } \\
\text { regularly. }\end{array}$ & -.195 & .338 & -.034 & .014 & -.024 & -.058 & .050 & .025 & .140 & -.023 & .554 & .078 \\
\hline Q10_1 & $\begin{array}{l}\text { (Project Monitoring and Control) You had been monitoring the actual values } \\
\text { of cost. }\end{array}$ & .036 & .301 & .055 & .052 & -.034 & .099 & -.042 & -.021 & -.084 & -.043 & .506 & .051 \\
\hline Q10_4 & $\begin{array}{l}\text { (Project Monitoring and Control) When you detected problem of progress } \\
\text { (cost, schedule, quality, etc.), you dealt with it appropriately. }\end{array}$ & -.023 & .387 & -.012 & -.048 & -.015 & .044 & -.022 & .038 & .007 & .077 & .498 & -.031 \\
\hline Q10_7 & $\begin{array}{l}\text { (Project Monitoring and Control) Your capability of the project monitoring } \\
\text { and control (project management skill, operation knowledge, etc.) was } \\
\text { enough. }\end{array}$ & .110 & .279 & -.106 & -.099 & -.027 & .106 & .019 & .082 & .033 & .041 & .477 & .138 \\
\hline Q10_2 & $\begin{array}{l}\text { (Project Monitoring and Control) You had been monitoring the actual values } \\
\text { of schedule. }\end{array}$ & -.004 & .276 & .048 & -.088 & .036 & .119 & -.006 & .038 & -.006 & .064 & .455 & -.010 \\
\hline Q10_6 & $\begin{array}{l}\text { (Project Monitoring and Control) When serious risk and issue became } \\
\text { apparent, you dealt with it appropriately. }\end{array}$ & -.059 & .304 & -.061 & -.110 & .067 & -.067 & .056 & -.034 & .111 & .113 & .441 & -.017 \\
\hline Q10_8 & $\begin{array}{l}\text { (Project Monitoring and Control) The resource for your project monitoring } \\
\text { and control (working hours, etc.) was enough. }\end{array}$ & .098 & .166 & -.011 & .076 & -.064 & .049 & .151 & .098 & -.030 & -.017 & .365 & .233 \\
\hline Q10_11 & $\begin{array}{l}\text { (Project Monitoring and Control) The ordering company had grasped the } \\
\text { situation of the project. }\end{array}$ & -.036 & .181 & -.153 & .222 & .103 & -.077 & .065 & -.026 & .149 & .266 & .276 & -.075 \\
\hline \multicolumn{14}{|c|}{ urce of Project Members } \\
\hline Q12_12 & $\begin{array}{l}\text { (Requirement Development) The project members' resource (working hours, } \\
\text { the number of members, etc.) was enough. }\end{array}$ & .385 & -.027 & -.027 & .180 & -.016 & .198 & .044 & -.021 & -.010 & .092 & -.028 & .458 \\
\hline Q16_7 & $\begin{array}{l}\text { (Test) The project members' resource (working hours, the number of } \\
\text { members, etc.) was enough. }\end{array}$ & .312 & -.121 & .200 & .012 & -.027 & .142 & .015 & .015 & .230 & .012 & .022 & .453 \\
\hline
\end{tabular}

$\begin{array}{llllllllllllll}-.024 & -.002 & .022 & \mathbf{. 8 2 8} & .059 & -.172 & -.057 & -.013 & -.055 & .056 & .063 & -.007\end{array}$

$\begin{array}{llllllllllllll}.018 & -.054 & .041 & .814 & .003 & -.072 & .024 & .057 & -.041 & -.084 & .009 & .152\end{array}$

$\begin{array}{lllllllllllll}.060 & -.001 & .004 & .803 & -.057 & -.200 & .021 & .025 & -.062 & .139 & -.024 & .113\end{array}$

$\begin{array}{llllllllllllll}.068 & .016 & .036 & .686 & -.053 & .062 & .019 & .045 & .005 & .041 & -.071 & .045\end{array}$

$\begin{array}{lllllllllllll}.031 & .071 & .048 & .447 & -.064 & .150 & -.049 & .066 & .075 & .117 & .128 & -.057\end{array}$

$\begin{array}{lllllllllllll}.021 & .054 & .200 & .383 & -.039 & .244 & -.036 & .076 & -.004 & .114 & -.111 & -.138\end{array}$

$\begin{array}{lllllllllllll}-.007 & .220 & .059 & .316 & -.001 & .223 & -.006 & .032 & .011 & .108 & -.039 & -.111\end{array}$

$\begin{array}{lllllllllllll}.006 & .071 & .015 & .003 & \mathbf{. 8 6 1} & -.055 & -.038 & .104 & -.077 & .018 & .024 & .022\end{array}$

$\begin{array}{lllllllllllll}-.019 & .012 & .011 & -.078 & .843 & .032 & .055 & -.001 & .012 & .048 & .042 & -.026\end{array}$

$\begin{array}{lllllllllllll}.067 & -.063 & .082 & -.016 & .691 & .097 & .001 & .104 & -.082 & .013 & -.084 & .038\end{array}$

$\begin{array}{lllllllllllll}.063 & .039 & -.039 & -.027 & .683 & .082 & .007 & -.066 & .088 & -.016 & .079 & -.065\end{array}$

$\begin{array}{llllllllllllll}-.010 & .043 & .029 & .184 & .447 & .109 & .051 & .017 & .026 & .010 & -.022 & -.022\end{array}$

$\begin{array}{llllllllllllll}.004 & -.143 & .008 & .044 & -.003 & -.075 & .872 & -.018 & .060 & .101 & .097 & .036\end{array}$

$\begin{array}{lllllllll}.023 & -.025 & \mathbf{. 8 0 9} & -.078 & -.001 & -.084 & -.045 & .063\end{array}$

$\begin{array}{llllllllllllll}.245 & .008 & -.041 & .064 & .026 & -.090 & -.013 & .793 & .021 & -.052 & .098 & -.070\end{array}$

\begin{tabular}{|lllllllll}
.072 & -.150 & -.034 & $\mathbf{. 6 5 0}$ & .320 & -.050 & .000 & .045 \\
.052 & .286 & .024 & .531 & -.043 & .035 & -087 & .144
\end{tabular}

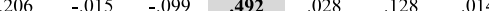

\begin{tabular}{llllllllllllll}
\hline 486 & -.028 & .001 & -.038 & .003 & .073 & .069 & -.016 & -.079 & $\mathbf{. 5 2 5}$ & -.149 & -.014
\end{tabular}

$\begin{array}{llllllllllll}166 & .291 & .037 & -.160 & -.015 & .029 & -.042 & -.037 & .001 & \mathbf{4 3 2} & .211 & -.059\end{array}$

$\begin{array}{llllllllllll}-.044 & .337 & 170 & .045 & 044 & -.158 & -.002 & 033 & -.011 & -.047 & \mathbf{. 6 0 1} & .014\end{array}$

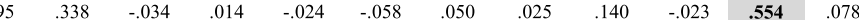

$\begin{array}{llllllllllll}.036 & .301 & .055 & .052 & -.034 & 099 & -.042 & -.021 & -.084 & -.043 & .506 & .05\end{array}$

$\begin{array}{llllllllllll}-.004 & 276 & .048 & -088 & 036 & .119 & -.006 & 038 & -006 & .064 & \mathbf{4 5 5} & -.010\end{array}$

$\begin{array}{llllllllllll}-.059 & 304 & -.061 & -.110 & .067 & -.067 & .056 & -.034 & .111 & 113 & \mathbf{4 4 1} & -.017\end{array}$

$\begin{array}{llllllllllll}.098 & .166 & -.011 & .076 & -.064 & .049 & .151 & 098 & -.030 & -.017 & \mathbf{3 6 5} & 233\end{array}$ 
Table 5 Factor characteristics.

\begin{tabular}{|c|c|c|}
\hline Factor & Factor Name & Factor Component Focus \\
\hline $\mathrm{X} 1$ & $\begin{array}{l}\text { Skill and Teamwork } \\
\text { of Project Members }\end{array}$ & $\begin{array}{l}\text { Relates to project members' operational and } \\
\text { technical skills, communication, and teamwork } \\
\text { during requirement development, design, } \\
\text { implementation, and testing }\end{array}$ \\
\hline $\mathrm{X} 2$ & Project Planning & $\begin{array}{l}\text { Relates to how the project was initially } \\
\text { conceptualized and developed in its early stages } \\
\text { (e.g., estimation of cost and schedule, specification } \\
\text { of risk, and stakeholder agreements) }\end{array}$ \\
\hline $\mathrm{X} 3$ & Acceptance Test & $\begin{array}{l}\text { Relates to components of acceptance testing, } \\
\text { including schedule estimation, work procedure } \\
\text { planning, member skill, and product quality }\end{array}$ \\
\hline $\mathrm{X} 4$ & $\begin{array}{l}\text { Ordering Company's } \\
\text { Skill and Requirement }\end{array}$ & $\begin{array}{l}\text { Relates to the operational and decision-making } \\
\text { skills and resource sufficiency of the ordering } \\
\text { company; also relates to success in completing the } \\
\text { development of particular requirements }\end{array}$ \\
\hline $\mathrm{X} 5$ & $\begin{array}{l}\text { Change Requirement } \\
\text { Management }\end{array}$ & $\begin{array}{l}\text { Relates to the verification of change requirements, } \\
\text { development of solutions for the change } \\
\text { requirements, and agreement upon those solutions }\end{array}$ \\
\hline $\mathrm{X} 6$ & $\begin{array}{l}\text { Detailed Planning and } \\
\text { Product Quality in } \\
\text { Each Phase }\end{array}$ & $\begin{array}{l}\text { Relates to schedule estimation, work procedure } \\
\text { planning, and product quality in requirement } \\
\text { development, design, implementation, and testing }\end{array}$ \\
\hline $\mathrm{X} 7$ & SM Involvement & $\begin{array}{l}\text { Relates to the degree to which the SM participates } \\
\text { in and supports the project }\end{array}$ \\
\hline$\overline{X 8}$ & $\begin{array}{l}\text { Schedule Progress in } \\
\text { Each Phase }\end{array}$ & $\begin{array}{l}\text { Relates to progress during requirement } \\
\text { development, design, implementation, and testing }\end{array}$ \\
\hline X9 & Test & $\begin{array}{l}\text { Relates to components of testing, such as work } \\
\text { procedure planning and product quality }\end{array}$ \\
\hline $\mathrm{X} 10$ & $\begin{array}{l}\text { Communication in } \\
\text { Requirement } \\
\text { Development Phase, } \\
\text { and Project } \\
\text { Monitoring and } \\
\text { Control } \\
\end{array}$ & $\begin{array}{l}\text { Relates to communication between the ordering } \\
\text { company, project members, and PM in requirement } \\
\text { development phase, and project monitoring and } \\
\text { control. }\end{array}$ \\
\hline $\mathrm{X} 11$ & $\begin{array}{l}\text { Project Monitoring } \\
\text { and Control }\end{array}$ & $\begin{array}{l}\text { Relates to components of project monitoring and } \\
\text { control, such as compiling observed costs, } \\
\text { schedules, quality, and scope, and developing } \\
\text { solutions to emergent problems }\end{array}$ \\
\hline $\mathrm{X} 12$ & $\begin{array}{l}\text { Resource of Project } \\
\text { Members }\end{array}$ & $\begin{array}{l}\text { Relates to the resource sufficiency of project } \\
\text { members in requirement development and testing }\end{array}$ \\
\hline
\end{tabular}

Table 6 Results of the multiple regression analysis.

\begin{tabular}{lccc}
\hline & Coefficient B & $\begin{array}{c}\text { Standardized } \\
\text { coefficient } \beta\end{array}$ & $p$-value \\
\hline Intercept & 4.612 & - & $<0.001$ \\
$\mathrm{X} 8$ & 0.361 & .396 & $<0.001$ \\
$\mathrm{X} 1$ & 0.282 & .318 & $<0.001$ \\
$\mathrm{X} 6$ & 0.138 & .154 & $<0.001$ \\
$\mathrm{X} 9$ & 0.115 & .124 & $<0.001$ \\
\hline $\mathrm{R}=.841$ & $\mathrm{R}^{2}=.708$ & Adjusted $\mathrm{R}^{2}=.706 \quad \mathrm{p}<0.001$ & \\
\hline Note: Predictor variables are listed in the order of their stepwise method \\
extraction.
\end{tabular}

were not adopted in the model illustrated in Fig. 2.

\subsection{Relationships between Factors}

In this section, we explain the relationships between the factors and the resulting model (as shown in Fig. 2). We describe all the factors listed in Fig. 2 in the order of their perceived proximity to project success. For each factor, we describe all the paths in the order of their respective coefficient strengths.

\subsubsection{The Influence of X4: Ordering Company's Skill and Requirement}

$\mathrm{X} 4$ is comprised of items related to the degree to which the ordering company possesses operational knowledge and decisionmaking skills, as well as the ordering company's capacity to complete requirements. This factor strongly influences the factor re-

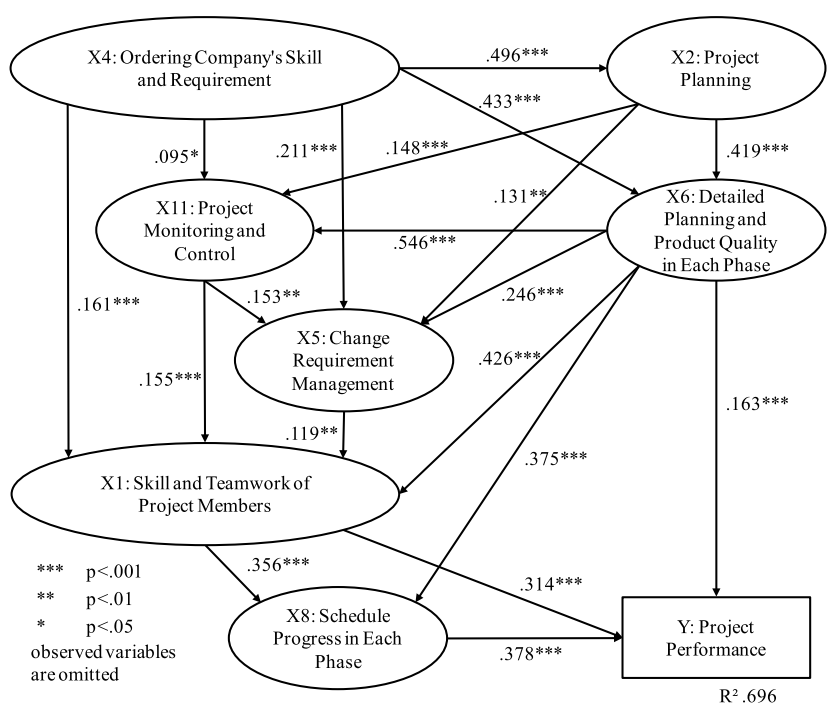

Fig. 2 Structure of factors that affect project performance.

Table 7 Structural equation model fit indices.

\begin{tabular}{rcccccc}
\hline $\begin{array}{c}\text { Chi-square } \\
\text { value }\end{array}$ & df & p-value & GFI & AGFI & RMSEA & AIC \\
10.405 & 9 & .319 & .995 & .980 & .017 & 64.405 \\
\hline
\end{tabular}

lated to project planning (X2). This association is likely due to the fact that clarifying the requirements and scope of an information systems development project during its early stages affects the accuracy with which a project plan can be followed. Related to this, X4 is also significantly correlated with the factor related to detailed planning and product quality in each phase (X6). This correlation likely results from the association between requirement completeness and product quality.

Our results also indicate that X4 significantly affects the Change Requirement Management factor (X5). Skill on the part of the ordering company yields proper specification of change requirements. As a result, it affects the quality of the changes IT vendors conduct. X4 also significantly affects the Skill and Teamwork of Project Members factor (X1). Requirement completeness affects project members' productive capacity. Finally, X4 significantly influences project monitoring and control (X11). As a form of project monitoring and control, the ordering company and IT vendor explore solutions when problems arise during the project. Hence, the ordering company's skill affects the quality of project monitoring and control activities.

Related to the relationships that emerged for X4, many studies have shown that issues related to users and requirements are predictive of project performance. For example, several empirical studies have demonstrated that users' skills and experience affect project performance [30], [31], [32]. Others have shown that clear definitions of project requirements are similarly related to project success [33], [34], [35], [36]. We believe that X4 is closely related to those factors explored in previous studies, thus explaining why it affects project performance and other factors.

\subsubsection{The Influence of X2: Project Planning}

The factor related to project planning (X2) represents the accuracy with which IT vendors' project planning activities are implemented in the project's early stages. Some of these activities include the estimation of cost and schedule, specification of risk, 
and stakeholder agreements. Because of the importance of planning in all stages of a project, this factor is significantly related to several others. First, X2 is shown to be significantly related to the Detailed Planning and Product Quality in Each Phase factor (X6). Generally, drawing up accurate project plans at the outset of a project positively affects the accuracy with which those plans are drawn up for each phase. Secondly, X2 is shown to significantly correlate with Project Monitoring and Control (X11). Generally, planning the outline of how to monitor and control project is considered to be a part of project planning activities. As such, effective implementation of project planning activities yields effective project monitoring and control. Finally, X2 significantly affects the Change Requirement Management factor (X5). Similar to project monitoring and control, the planning outline of how to manage changes in requirements is also a key part of project planning activities. Thus, effective implementation of project planning activities leads to effective management of changes in requirements.

Past research has demonstrated that as an explanatory factor, project management affects project performance. For example, many empirical studies have shown that each activity associated with project planning significantly influences project performance [33], [37], [38], [39], [40], [41]. Given X2's similarity with project management, it is logical that it also affects project performance in a comparable fashion.

\subsubsection{Influence of X6: Detailed Planning and Product Qual- ity in Each Phase}

The Detailed Planning and Product Quality in Each Phase factor (X6) relates to planning accuracy and product quality in each phase. Similar to the above factors, X6 is also significantly related to several variables in our model.

Foremost, there is a positive relationship between X6 and Project Monitoring and Control (X11). Defining procedures of monitoring and control is usually a part of detailed planning in each phase, thus effective detailed planning will definitely yield successful implementation of project monitoring and control. Second, X6 is shown to influence Skill and Teamwork of Project Members (X1). This relationship is likely due to the inherent associations between detailed schedules, work procedures, and performance capabilities. Third, X6 affects the Schedule Progress in Each Phase factor (X8), because the planning and implementation of a detailed schedule and work procedures affects project progress in each phase. Fourth, the factor affects Change Requirement Management (X5). Similar to project monitoring and control, defining procedures of change requirement management is usually a part of detailed planning in each phase. Therefore, effective detailed planning positively affects a firm's ability to perform change requirement management activities. Finally, $\mathrm{X} 6$ is shown to significantly influence the outcome measure, (Y). This finding was expected, as product quality in each phase is implicitly associated with the quality of a project outcome.

Because X6 is so closely related to project planning (X2), their relationships with other variables in the model are quite similar.

\subsubsection{Influence of X11: Project Monitoring and Control}

The factor entitled Project Monitoring and Control (X11) is related to the accurate monitoring and controlling of project activ- ities. These activities include compiling observed costs, schedules, quality, and scope, and developing solutions to emergent problems. X11 is correlated with several other factors. First, X11 significantly influences the Skill and Teamwork of Project Members factor (X1). Project monitoring and control promotes information sharing between project members, and reduces misunderstandings among them. As a result, effective monitoring practices improve project members' teamwork and performance capacities. Second, there is a positive relationship between X11 and the factor called Change Requirement Management (X5). Generally, project monitoring and control also closely relates to the management of change requirements. Given this, effective project monitoring and control reduces problems associated with change requirement management activities.

Some past research has provided evidence that project monitoring and control activities affect project performance. For example, as in the observed relationship between X11 and X1, some researchers have shown that project monitoring and control promotes information sharing and cooperation among project members, which, in turn, affects project performance [38], [39], [40], [42], [43], [44], [45], [46].

\subsubsection{Influence of X5: Change Requirement Management}

The factor titled Change Requirement Management (X5) is related to the proper implementation of change requirement management practices. Some of these practices include verification of change requirements, development of solutions for the change requirements, and agreement upon those solutions. Our results demonstrate that similar to X11, X5 is closely related to the Skill and Teamwork of Project Members factor (X1). A significant number of change requirements or the development of improper solutions for those requirements can cause confusion among project members, which can reduce productivity. Therefore, effective change requirement management influences project members' respective capabilities such that their productivity and teamwork ability improve.

Past research has set a precedent for these relationships. Change requirement management has often been cited as a factor that affects project performance. For example, instability or volatility has been shown to lead to project problems [45], [47], [48], [49]. Given the similarity of how change management has been conceptualized in past research relative to our definition of $\mathrm{X} 5$, it seems clear that the factor affects not only project performance, but other explanatory factors as well.

\subsubsection{Influence of X1: Skill and Teamwork of Project Mem- bers}

Factor X1, which relates to project members' abilities and teamwork, is strongly related to several variables in our model. First, X1 is associated with the Schedule Progress in Each Phase factor (X8). This relationship seems commonsensical, as project members' capabilities and capacity for teamwork promote productivity and also affect progress in each phase. X1 also strongly affects the outcome variable, project performance (Y). Just as skills and teamwork affect progress in each phase, they promote the attainment of project goals related to quality, cost, and scope.

Similar to the findings we report here, studies have shown that developer skill and teamwork influence project performance. 
This work has shown that they contribute to positive project results, as it allows skilled project members to be assigned to critical roles [35], [43], [47], [50], [51]. Moreover, cooperation among the project team's members has been shown to strongly influence project performance [52], [53].

\subsubsection{Influence of X8: Schedule Progress in Each Phase}

The factor entitled Schedule Progress in Each Phase (X8) relates to the attainment of projected schedule goals in each phase of production. As expected, this factor strongly influences final project performance (Y). This is likely the result of a strong relationship between quality across each phase and the quality of the final project outcome.

\section{Discussion}

\subsection{The Extracted Factors}

As mentioned in Section 5, many of the extracted factors had been previously shown to affect project performance in past research. Within their respective classifications for "People and Action" and "Development Processes," McLeod and MacDonell [4] identified several important factors, including developers, users, top management, project team, social interaction, requirements determination, project management, and user participation. The results of our survey indicate that most of McLeod and MacDonell's [4] classifications are warranted. However, top management and user participation did not emerge as predictive factors in this study. Top management relates to the management's participation in and positive support for projects. Previous work has identified this factor as influential of project performance [34], [43], [44], [51], [54], [55], [56], [57], [58]. According to this work, in projects that require user participation, management support has been shown to be particularly useful for improving project performance. Despite its failure to emerge as its own factor in our data, management support for users is critical within ordering companies. As such, factor X4: Ordering Company's Skill and Requirement, incorporates its influence. Moreover, because IT vendors typically compose a team for each respective systems development project, negotiation of stakeholders' participation in IT vendors' activities is essentially unnecessary. Therefore, management support influences IT vendors relatively little. "User participation" is similarly a component of factor X4. Therefore, its influence is accounted for as well.

Thus, from the perspective of an IT vendor, there are some implications of the failure of our data to produce factors explicitly related to top management and user participation. However, the tendency of factors that affect the project performance identified by this research, and the factors discussed by the previous works are common.

\subsection{Proposal for Project Performance Improvement}

As shown in Fig. 2, many of the extracted factors are interdependent. To clarify our understanding of how these factors operate together and independently, we reduced the path model shown in Fig. 2 such that only those paths with a weight of 0.2 or greater were extracted. This model is shown in Fig. 3. Although they have input paths which were above 0.2 , factors X11 and X5 did not have output paths of 0.2 or greater, and were thus removed.

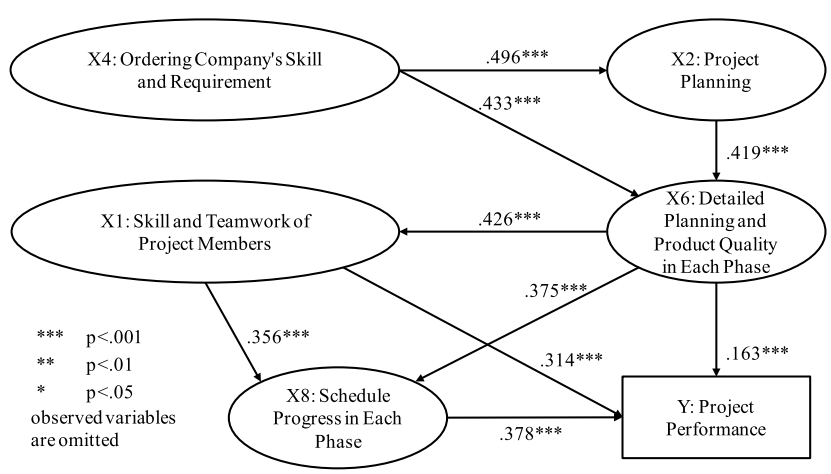

Fig. 3 Structure of factors that affect project performance (stronger paths included).

From Fig. 3, we propose two points for improvement of project performance of IT vendors in Japan.

First, we suggest that a dedication to supplying resources and achieving requirement completeness for the ordering company is critical for project performance. The factor entitled Ordering Company's Skill and Requirement was shown to be very important for project performance. Because this factor relates specifically to the ordering company, the IT vendor cannot directly affect it. However, it is possible to indirectly contribute to the ordering company's skills and requirements through two activities: proposing a reorganization of the ordering company's resources or requesting a review of the requirement development procedures employed by the ordering company.

Second, our results (see results for X2 and X6) demonstrate the importance of project planning for productivity and ultimate project performance. As such, we recommend three activities that may lead to the improvement of outcomes contingent on planning. These activities include carefully planning separate activities (e.g., estimation, agreement with stakeholders, and specification of risks); clarifying work procedures and schedules associated with each phase of production; and carefully planning each phase of the project with an emphasis on monitoring, control, and change requirement management.

\section{Conclusion}

In this study, we focused on two key points that affect performance of information systems development: the IT vendor and relationships between explanatory factors. We utilized an Internet questionnaire and SEM to explore these issues. Results indicate that seven factors, Ordering Company's Skill and Requirement, Project Planning, Detailed Planning and Product Quality in Each Phase, Project Monitoring and Control, Change Requirement Management, Skill and Teamwork of Project Members, and Schedule Progress in Each Phase simultaneously influence project performance and each other. Many of these factors have been established as influential of project performance in past research. However, this study provides two key contributions to the literature. These include clarifying the differences between factors identified from the perspective of the IT Vendor and described in previous research, and more importantly, illustrating the relationships between the specified factors and identifying important factors for the IT Vendor.

To extend the findings uncovered here, future research should 
consider the following four points.

First, the types of development life cycles of project should be considered. Owing to the fact that $85-95 \%$ of the development projects in Japan have adopted the waterfall development life cycle [1], [21], this research made applicable to investigation for the projects that adopt the development life cycle. However, it is said that approximately $84 \%$ of projects have adopted development life cycles other than the waterfall model in the world [22]. It is predicted that the projects that adopt these development life cycles such as Agile model will increase in the future in Japan. Therefore, research should be conducted for the projects that adopt the development life cycles other than the waterfall model. Further, these results should be compared with results of this research.

Second, factor classifications affecting project performance should be considered. The questionnaire of this research covers "Development Processes" and "People and Action" of four factor classifications, which McLeod and MacDonell [4] showed, because CMMI was adopted as a reference model. On the other hand, the questionnaire does not include the other factor classifications related to "Institutional Context" and "Project Content" that contain factors such as project size and technical newness. Because Project Content may strongly influence project performance, investigation should be conducted by carrying out the questionnaire that includes these factor classifications.

Third, research respondents should be considered. In order to clarify factors that affect project performance from the viewpoint of the IT vendor project, the PM of the IT vendor was elected as a questionnaire respondent in this research. Because the PM understands project outcome and detailed project situations, it can be that the PM is appropriate as a questionnaire respondent. However, by gathering data from different respondents directly involved in development projects such as project team members of the IT vendor, unknown knowledge might be acquired.

Finally, thorough investigation for project cancellation should be considered. Because SEM and multiple regression analysis cannot deal with missing data, this research analyzed the data excepting the data of project cancellation ( $7.5 \%$ of our data). However, although cancellation is not always a failure, it is worth investigating because challenging problems such as the inability of IT vendors to develop a complete product can be studied. Other methods such as interviews should be conducted to clarify causes that lead to project cancellation.

Acknowledgments This research was supported by the Global COE Program of Japan's Ministry of Education, Culture, Sports, Science and Technology and the Doctoral Course Student Research Support Program of Keio University. We respectfully express gratitude to the staffs of the Graduate School of System Design and Management at Keio University and the employees within the IT vendor firms who contributed to this research.

\section{References}

[1] Japan Users Association of Information Systems: 17th IT trend survey for companies 2011 (online), available from 〈https://www.juas.or.jp/ servey/it11/it11_summary.pdf (accessed 2013-02-19).

[2] United States Department of Commerce: National economic accounts (online), available from 〈http://www.bea.gov/national/xls/ soft-invest.xls $>$ (accessed 2013-02-19).

[3] Japan Ministry of Economy, Trade and Industry: Specific service industries survey Heisei 212011 (online), available from 〈http://www.meti.go.jp/statistics/tyo/tokusabizi/result-2/h21/pdf/ h21 outline01.pdf $\rangle$ (accessed 2013-02-19).

[4] McLeod, L. and MacDonell, S.G.: Factors that affect software systems development project outcomes: A survey of research, ACM Computing Surveys, Vol.43, No.4, Article24 (2011).

[5] Nikkei Business Publications: Project survey of 800 Companies, Nikkei Computer, pp.36-49 (Dec. 2008).

[6] The Standish Group International: CHAOS Summary 2009, The Standish Group International, Boston, MA (2009).

[7] Fitzgerald, B.: An empirically-grounded framework for the information systems development process, Proc. International Conference on Information Systems, Paper 10 (1998).

[8] Fitzgerald, B., Russo, N.L. and Stolterman, E.: Information Systems Development: Methods in Action, McGraw-Hill, New York (2002).

[9] Iivari, N.: Enculturation of user nvolvement in oftware evelopment organizations - An interpretive case study in the product development context, Proc. 3rd Nordic Conference on Human-Computer Interaction, pp.287-296, ACM Press, New York (2004).

[10] Furuyama, T., Kikuchi, N., Yasuda, M. and Tsuruho, S.: Analysis of the factors that affect the performance of software projects, Trans. Information Processing Society of Japan, Vol.48, No.8, pp.2608-2619 (2007).

[11] Jun, L., Quizhen, W. and Quingguo, M.: The effects of project uncertainty and risk management on IS development project performance: A vendor perspective, International Journal of Project Management, Vol.29, pp.923-933 (2011).

[12] The Standish Group International: CHAOS Report 1995, The Standish Group International, Boston, MA (1995).

[13] Gowan, Jr., J.A. and Mathieu, R.G.: The importance of management practices in IS project performance, Journal of Enterprise Information Management, Vol.18, No.2, pp.235-255 (2005).

[14] Kawamura, T. and Takano, K.: Research on factors of the organizational culture that affect the performance of information systems development, Trans. Information Processing Society of Japan, Vol.53, No.12, pp.2854-2864 (2012).

[15] Wixom, B.H. and Watson, H.J.: An empirical investigation of the factors affecting data warehousing success, MIS Quarterly, Vol.25, No.1, pp.17-41 (2001).

[16] Kosugi, M. and Hasegawa, N.: A preliminary study on factors constructing trust in public and private organizations, Report of Central Research Institute of Electric Power Industry, Y08040 (2009).

[17] Muranaka, A. and Nakaya, T.: Effects of data collection methods in social surveys on the willingness to pay: A Comparative study between mail survey and web survey, Environmental Information Science, Vol.38, No.1, pp.47-55 (2009).

[18] Japanese Information-Technology Promotion Agency: IT project visualization: Upper phase edition, Nikkei Business Publications, Tokyo (2007).

[19] Japanese Information-Technology Promotion Agency: IT project visualization: Middle phase edition, Nikkei Business Publications, Tokyo (2008).

[20] Japanese Information-Technology Promotion Agency: IT project visualization: Lower phase edition, Nikkei Business Publications, Tokyo (2006).

[21] Japanese Information-Technology Promotion Agency: Software development white paper 2012-2013, Nikkei Business Publications, Tokyo (2012).

[22] West, D. and Grant, T.: Agile development: Mainstream adoption has changed agility, Forrester Research, Cambridge, MA (2010).

[23] Carnegie Mellon University, CMMI for development, Version 1.3 (2010).

[24] Delone, W.H. and Mclean, E.R.: The Delone and Mclean model of information systems success: A ten-year update, Journal of Management Information Systems, Vol.19, No.4, pp.9-30 (2003).

[25] Riley, L. and Smith, G.: Developing and implementing IS: A case study analysis in social services, Journal of Information Technology, Vol.12, No.4, pp.305-321 (1997).

[26] Emam, K.E. and Koru, A.G.: A replicated survey of IT software project failures, IEEE Software, Vol.25, No.5, pp.84-90 (2008).

[27] Japanese Information-Technology Promotion Agency: Average age of engineer examination for information processing (online), available from 〈http://www.jitec.ipa.go.jp/1_07toukei/heikin_nenrei.pdf〉 (accessed 2013-02-19).

[28] Nikkei Business Publications: Analysis of skill level from various viewpoints, Nikkei IT Professional, pp.47-52 (Oct. 2005).

[29] Project Management Institute: A guide to the project management body of knowledge, fourth edition, Project Management Institute, Newtown Square, PA (2008). 
[30] Jiang, J.J. and Klein, G.: Risks to different aspects of system success, Information $\mathcal{E}$ Management, Vol.36, No.5, pp.263-272 (1999).

[31] Jiang, J.J. and Klein, G.: Software development risks to project effectiveness, Journal of Systems and Software, Vol.52, No.1, pp.3-10 (2000).

[32] Mahmood, M.A., Burn, J.M., Gemoets, L.A. and Jacquez, C.: Variables affecting information technology end-user satisfaction: A metaanalysis of the empirical literature, International Journal of HumanComputer Studies, Vol.52, No.4, pp.751-771 (2000).

[33] Lemon, W.F., Liebowitz, J., Burn, J.M. and Hackney, R.: Information systems project failure: A comparative study of two countries, Journal of Global Information Management, Vol.10, No.2, pp.28-39 (2002).

[34] Procaccino, J.D., Verner, J.M., Darter, M.E. and Amadio, W.J.: Toward predicting software development success from the perspective of practitioners: An exploratory Bayesian model, Journal of Information Technology, Vol.20, No.3, pp.187-200 (2005).

[35] Procaccino, J.D., Verner, J.M. and Lorenzet, S.J.: Defining and contributing to software development success, Comm. ACM, Vol.49, No.8, pp.79-83 (2006).

[36] Verner, J.M. and Evaco, W.M.: In-house software development: What project management practices lead to success?, IEEE Software, Vol.22, No.1, pp.86-93 (2005)

[37] Aladwani, A.M.: IS project characteristics and performance: A Kuwaiti illustration, Journal of Global Information Management, Vol.8, No.2, pp.50-57 (2000).

[38] Barki, H., Rivard S., and Talbot, J.: An integrative contingency model of software project risk management, Journal of Management Information Systems, Vol.17, No.4, pp.37-69 (2001).

[39] Butler, T. and Fitzgerald, B.: Unpacking the systems development process: An empirical application of the CSF concept in a research context, Journal of Strategic Information Systems, Vol.8, No.4, pp.351371 (1999).

[40] Kim, C.S. and Peterson, D.K.: A comparison of the perceived importance of information systems development strategies by developers from the United States and Korea, Information Resources Management Journal, Vol.16, No.2, pp.1-18 (2003).

[41] Mabert, V.A., Soni, A. and Venkataramanan, M.A.: Enterprise resource planning: Managing the implementation process, European Journal of Operational Research, Vol.146, No.2, pp.302-314 (2003).

[42] Peterson, D.K., Kim, C., Kim, J.H. and Tamura, T.: The perceptions of information systems designers from the United States, Japan, and Korea on success and failure factors, International Journal of Information Management, Vol.22, No.6, pp.421-439 (2002).

[43] Jiang, J.J., Klein, G. and Balloun, J.: Ranking of system implementation success factors, Project Management Journal, Vol.27, pp.50-55 (1996).

[44] Pan, G.S.C., Pan, S.L. and Flynn, D.: De-escalation of commitment to information systems projects: A process perspective, Journal of Strategic Information Systems, Vol.13, No.3, pp.247-270 (2004).

[45] Schmidt, R., Lyytinen, K., Keil, M. and Cule, P.: Identifying software project risks: An international Delphi study, Journal of Management Information Systems, Vol.17, No.4, pp.5-36 (2001).

[46] Wang, E.T.G., Shih, S., Jiang, J.J. and Klein, G.: The relative influence of management control and user-IS personnel interaction on project performance, Information and Software Technology, Vol.48, No.3, pp.214-220 (2006).

[47] Barry, C. and Lang, M.: A comparison of 'traditional' and multimedia information systems development practices, Information and Software Technology, Vol.45, pp.217-227 (2003).

[48] Keil, M., Cule, P.E., Lyytinen, K. and Schmidt, R.C.: A framework for identifying software projects risks, Comm. ACM, Vol.41, No.11, pp.76-83 (1998).

[49] Oz, E. and Sosik, J.J.: Why information systems projects are abandoned: A leadership and communication theory and exploratory study, Journal of Computer Information Systems, Vol.44, No.1, pp.66-78 (2000).

[50] Keil, M., Tiwana, A. and Bush, A.: Reconciling user and project manager perceptions on IT project risk: A Delphi study, Information Systems Journal, Vol.12, No.2, pp.103-119 (2002).

[51] Somers, T.M. and Nelson, K.: The impact of critical success factors across the stages of enterprise resource planning implementations, Proc. 34th Hawaii International Conference on System Sciences, Vol.8, p.8016 (2001).

[52] Jiang, J.J., Klein, G. and Discenza, R.: Pre-project partnering impact on an information system project, project team and project manager, European Journal of Information Systems, Vol.11, pp.86-97 (2002).

[53] Wang, E., Chou, H. and Jiang, J.: The impacts of charismatic leadership style on team cohesiveness and overall performance during ERP implementation, International Journal of Project Management, Vol.23, No.3, pp.173-180 (2005).

[54] Akkermans, H. and van Helden, K.: Vicious and virtuous cycles in
ERP implementation: A case study of interrelations between critical success factors, European Journal of Information Systems, Vol.11, pp.35-46 (2002).

[55] Aladwani, A.M.: An integrated performance model of information systems projects, Journal of Management Information Systems, Vol.19, No.1, pp.185-210 (2002)

[56] Belassi, W. and Tukel, O.I.: A new framework for determining critical success/failure factors in projects, International Journal of Project Management, Vol.14, No.3, pp.141-151 (1996).

[57] Newman, M. and Sabherwal, R.: Determinants of commitment to in formation systems development: A longitudinal investigation, MIS Quarterly, Vol.20, pp.23-54 (1996).

[58] Sharma, R. and Yetton, P.: The contingent effects of management support and task interdependence on successful information systems implementation, MIS Quarterly, Vol.27, No.4, pp.533-555 (2003).

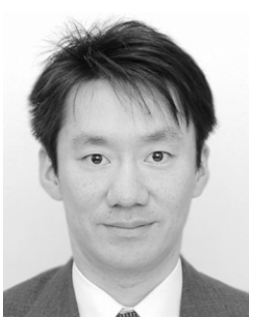

Tomoyuki Kawamura received his M.Sc. degree in systems engineering from Keio University in 2012. He has worked at ISI -Dentsu, Ltd., Tokyo, Japan since April 1995. He is also a Ph.D. student and a part-time lecturer at Keio University. His research interests include project management and organization management of IS development. He is a member of IPSJ and IEEE.

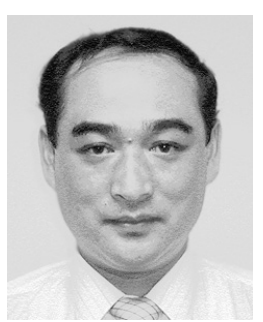

Kenichi Takano received his M.E. and D.E. degrees from Nagoya University in 1980 and 1995 respectively. He worked at Central Research Institute of Electric Power Industry (CRIEPI) from 1980. He is currently a professor at Keio University. His research interests include risk management, human factor, and safety culture of technical systems. He is a committee of Japan industrial safety and health association (JISHA). 